УДК 821.161 .1

Рева-Лсвиакова Л. В.

доктор філологічних наук, професор

Ізмайльський державний гуманітарний університет

\title{
НЕОРЕАЛІЗМ М. ГОРЬКОГО: ЛІТЕРАТУРОЗНАВЧІ СТУДІЇ
}

У статті досліджуються теоретичні розвідки літературознавців про синтетизм стилю М. Горького. До аналізу залучено літературознавчі праці науковців минулого і сучасності. Особлива увага приділяється неореалістичним рисам у творчості письменника, розвиток яких припадає на першу третину XX століття.

Ключові слова: синтетизм, неореалізм, модернізм, реалізм.

B статье рассматриваются литературоведческие исследования синтетичности стиля М. Горького. К анализу привлечены литературоведческие 
работы ученых промлого века и современного периода. Особое внимание уделяется неореалистическим чертам в творчестве писателя, развитие которых приходится на первую треть ХX века.

Ключевые слова: синтетизм, неореализм, модернизм, реализм.

The article deals with literary studies of M.Gorky's synthetical style. The analysis involues literal works of the scientists of the last century and modern period. Particular attention is paid to neorealist features in the works of the writer, the development of which occurs in the first third of the XXth century.

Key words: sintetizm, neorealism, modernism, realism.

Про М. Горького (1868-1936) написано багато як його співвітчизниками i зарубіжними колегами, так i послідовникамилітераторами та критиками. У працях про письменника зустрічається різна тематична спрямованість: розвідки про знайомство 3 відомими людьми, опрацювання переписки 3 Л. Андреєвим, В. Брюсовим, I. Буніним, В. Винниченком, В. Короленком, М. Пришвіним, В. Розановим, Р. Ролланом, С. Сергеєвим-Ценським, А. Чеховим та іншими його сучасниками, вивчення ліній творчих контактів із письменниками та видавництвами, дослідження участі у літературних гуртках i спілках, розвідки про біографічні, родові та сімейні історії.

Перші критичні праці про молодого письменника належали M. Михайловському, О. Скабічевському, Д. Мережковському, В. Воровському, Д. Овсянико-Куликовському, А. Луначарському, В. Львову-Рогачевському. 3 30-х років минулого століття визначилося коло провідних літературознавців - дослідників творчої спадщини М. Горького, зокрема: С. Балухатий, Б. Бялік, І. Груздєв, В. Десницький, С. Касторський, К. Муратова, М. Піксанов, Ю. Юзовський. У 50 - 80-ті роки коло розширилось, до нього увійшли В. Барахов, Б. Бурсов, О. Волков, Н. Кузьмичов, Б. Михайловський, О. Мясников, О. Овчаренко, В. Панков, Л. Спиридонова, С. Тагер та інші. На рубежі XX - XXI століть 3’явилися нові імена й дослідження В. Барахова («М. Горький на пороге 
XXI столетия: поиски научной мысли и массовая литература», 1998), В. Муромського («Все дальше от канона: новые труды о Горьком», 1997), Л. Спиридонової («Горьковедение на рубеже веков», 2001), а також праці П. Басинського, І. Вайсберга, Л. Сгорової і П. Чєкалової, І. Ссаулова, Г. Мітіна, Р. Пєвцової, Н. Примочкіної, Л. Рєзнікова, А. Синявського, С. Сухих та інших. Наголос часу наприкінці XX століття змінив напрям літературознавчого вивчення М. Горького, творчість його почали переоцінювати, тому з'явилися нові погляди на естетичну своєрідність творів. Усім відомий родоначальник соціалістичного реалізму став цікавим для виявлення в його творах модерністських рис.

До модерністських інтенцій у наукових дослідженнях горьківської спадщини існувало дві лінії пошуку. Перша пов'язана 3 пошуками доказів належності творчості до методу соцреалізму, в основі другої - роздуми про стильовий реалістично-романтичний синтез епосу. Проблему синтезу у творчості письменника дослідник С. Венгеров на початку XX століття визначив так: «Щодо літературної манери Горького, то <..> романтичне забарвлення ї̈ могло з'явитися лише в таку епоху, коли реалізм змарнів $i$ з'явилася потреба оминути побут» [Венгеров 1909 : 57]. Наслідки такого відволікання, на думку С. Венгерова, становили кілька мотивів: вплив піднесення суспільної свідомості, ніцшевське уявлення про надлюдину, історія розумового розвитку М. Горького. На стильовому синтезі наполягав В. Гречнєв, який виокремив дві постійні тенденції у художній практиці митця: реалізм і романтизм. В. Гречнєв писав: «3 одного боку, оптимістичне, романтично піднесене відношення до людини, оспівування благородства, достоӥнства і краси, а з іншого - розсудливо реалістичний погляд на потворні умови дійсності, безщзадна критика $і$ викриття ичих умов» [Гречнев $1979: 156]$. Синтетичний характер творчості надав можливості критикам говорити про розвиток нового напряму російської літератури на початку XX століття.

Нові наукові характеристики підтримувалися висловами А. Луначарського про поєднання «старого i нового реалістичного спостереження» в «ультраромантичних оповіданнях» М. Горького 
[Луначарский $1958: 384]$. Критичні міркування про «старі» й «нові» авторські обсервації лягли в основу досліджень жанрових характеристик творів. У наукових поглядах на жанрову своєрідність простежується спільність поглядів про об’єднання епічної описовості та ліричної суб'єктивності. М. Горький обстоював «епічний спокій» у літературі й намагався створити новий симбіотичний рівень слова, у якому б не було пафосу і патетики. Стильові пошуки письменника засвідчено не тільки в епістолярній спадщині, статтях, а й у художній практиці. У запереченні пафосу і патетики автор суперечив собі, адже у багатьох його творах романтичність межує з надзвичайним емоційним піднесенням, що нагадує пафосну риторичність. Ліричний наголос розширював творчі обрії у відображенні дійсності. Визначення жанрової ліро-епічності В. Келдиш пояснював створенням нового реалістичного стильового руху, він помічав, що у процесі нового реалізму на початку XX століття «ліричний герой автора втрачає незалежність, розчиняється в картині, є структурним елементом зовнішнього “об'єкту”» [Келдыш 1975 : 199]. За доказами дослідника, це уможливило розвиток двох зустрічних тенденцій: ліричної та емоційно-узагальненої на основі розширення емпіричних кордонів наочного образу. Ліро-епічний синтез тенденцій призводив до нових домінант художності, що давало змогу говорити про зародження нової стильової основи. 3 появою наприкінці минулого століття модерністського визначення горьківської творчості відбувалось подальше розширення наукових студій щодо жанрово-стильової своєрідності, засади якої вбачались у ліро-епічному поєднанні мистецьких надбань.

Суперечливу позицію обстоював Б. Бялік, котрий наполягав на факті належності горьківської творчості до соціалістичного реалізму, що для нього становив суть «нового реалізму». Однак автор досліджень про зародження соцреалізму також помічав синтетичний характер доробку письменника. Романтичну забарвленість і реалістичне зображення Б. Бялік подавав як конфлікт різних середовищ (народної та інтелігентської), що були добре відомі автору. Різне оточення позначилось у М. Горького 
створенням двох епічних груп: «До першої групи творів належали ті, в яких життя зображувалося у формах самого життя, до другої - ті, в яких переважали умовні форми: алегорії, сатиричний гротеск і т. п.» [Бялик 1974 : 258]. Ці характеристики критик відносив до ранньої творчості письменника: «У “нарисах”, при всій їх реалістичності, є і безперечний романтизм, а “оповідання", при всій фантастичності включених у них казок і легенд, пройняті справжнім реалізмом. Факт існування в ранній творчості Горького різних жанрово-стильових ліній безперечний» [Бялик 1974 : 259]. Б. Бялік не виключав можливості ширшого трактування творчого методу митця, у творах якого він помітив символізацію, багатобарвну експресію, вразливу описовість, що становили «суб'єктивне свавілля» творчої особистості.

Паралелізм визначень - новий реалізм = соцреалізм - спостерігається у ранній праці В. Келдиша про розвиток реалізму початку XX століття. Порівнюючи ставлення М. Горького і А. Чехова до розвитку нового типу літератури, В. Келдиш зазначав: «Відмінність стильових принципів Горького i Чехова виразилася набагато ширше у своєму значенні i неминучій суперечності між одним із великих завершувачів російського критичного реалізму і зачинателем нового реалізму - соціалістичного» [Келдыш 1975 : 184]. У той же час критик помічав, що «незгода Чехова $з$ “нестриманістю” ... мистецтва, яке Горький називав “збуджуючим”, ... мало відношення до стильових прочесів у російському реалізмі, пов'язаних не лише з новою ідеологією» [Келдыш 1975 : 184]. Помітно, що автор відчував новий естетичний присмак реалізму. Це розуміння надало можливість дійти новочасних для періоду 70-х років минулого століття висновків, які змусили наукове коло пошукачів замислитися не на одне десятиліття. Критик стверджував, що на початку XX ст. одночасно 3 реалістичним стилем розвивався й інший, біля витоків якого стояв ранній М. Горький. До рис нового стилю В. Келдиш відносив напруженоемоційну образну мову, прагнення розхитати канон об'єктивності стилю та вийти за його кордони, вступ у контакт із поетикою нереалістичних художніх напрямів. Про специфіку нового реалістичного руху він писав: 
«Усередині нього можна виділити ... різні лінії. В одному випадку це звернення до романтичної образності; у іншому - до окремих рис модерністської поетики» [Келдыш 1975 : 179]. У зв’язку зі співпрацею нових реалістів гуртка «Среда» і товариства «Знание» (яке очолював М. Горький) Б. Катаєв зазначав: «... головна зміна у художньому світі Горького на рубежі століть - зміна його орієнтаиії на читача і пов'язана з нею спроба сформувати нову структуру письменницького світогляду стали основою естетичної програми нового літературного об'єднання» [Катаев $2000: 236]$. Художньою платформою нових реалістів стали твори М. Горького, а також концепції, які він висловлював у листах до сучасників. «Не обслуговувати традиџійного читача $i$ не поставляти йому новини про життя, а давати відчувати йому невідворотність знищення $і$ загибелі того, що здавалося сталим і міщним, що виправдовує грубу правду діалогу з ним!» [Катаев 2000 : 235], - так окреслював дослідник основу неореалізму М. Горького.

У зв'язку з проблемами стильової своєрідності творів письменника наприкінці минулого століття 3'являються нові дослідження американських славістів. Так, Е. Дж. Браун у новому реалізмі М. Горького вбачав поєднання символізму i декадансу. Погляди професора на мистецький симбіоз відтворюють концептуальні положення філософівнеореалістів про об'єднувальний характер усього існуючого у світі. Тому Е. Дж. Браун пропонував корені симбіозу шукати в загальній літературній системі, в рамках якої М. Горький з'явився і справив потужне враження. Підгрунтям цих міркувань стали розвідки Б. Томашевського та Б. Ейхенбаума про реальну біографію митця і літературну легенду його походження. Творчість М. Горького славіст називає складним розширеним символом, поява якого у літературі стала незвичайним фактом: «Горький був введений $у$ літературну ієрархію, на верхньому рівні якої ... знаходилися символісти з $а \ddot{x}$ інтенсивною иікавістю до літературної техніки ... $з$ їх заглибленістю у питання релігії $i$ філософії $i$ з їх трактуванням літературного середовища як “іншого” (“світського”) 
життя» [Браун 1993 : 167]. Дослідження Е. Дж. Брауна спрямовані на встановлення складної грані мистецької художності, у якій він убачав тяжіння М. Горького більше до модернізму, ніж до реалізму. Однак специфіку модерністського тяжіння автор пов'язував із символістськими нахилами російського митця. Власні ідеї критик підкріплював історіями про творчі контакти М. Горького $з$ відомими символістами Андреєм Бєлим, О. Блоком, В. Брюсовим. Щоправда, американський славіст не згадує про суперечку М. Горького і Л. Андреєва у питаннях про ідеї нових реалістів гуртка «Среда». Відомо, що Л. Андреєв наполягав розширити кордони нового реалізму за рахунок символізму, а також увести до кола літераторів символіста О. Блока. Це викликало крайню незгоду М. Горького. Однак ситуації взаємин - це історичні факти, а літературознавство розвивається за власними законами, основою яких лишається пошук та наукова спрямованість на відкриття нового, невідомого.

Наукові студії І. Захарієвої скеровані на виявлення симбіотичних рис символізму i реалізму на засадах неореалізму. Символізацію (як міфологізацію) авторка вбачала у новелістичному циклі «Сказки об Италии» (1911-1913). На основі висловлень Г. Струве, Л. Ржевського про роман російського зарубіжжя 1920-1930-х років вона називала неореалістичним роман «Дело Артамонових» (1925), у якому помічала «систему авторських прийомів символізачії реалістичного методу», оскільки «романістіка М. Горького доводила виснаженість російського класичного реалізму як творчого методу XX століття» [Захариева 2003 : 36]. Дослідниця зазначала, що у творах емігрантського періоду М. Горького, I. Буніна, О. Купріна, Б. Зайцева переважав підвищений ліризм, з'явився особисто забарвлений міфологізм, на основі цих рис «сформувалася оригінальна жанрово-стильова модель російського емігрантського роману, до якого застосовано визначення “неореалістичний”» [Захариева $2003: 36]$.

Неореалістичні студії І. Кондрашевої побудовано на новій концепції особистості, у створенні якої М. Горький віднайшов свій «промінь зору» 
на життя. До авторських досліджень залучені твори «Мальва», «Коновалов», «Макар Чудра», «Старуха Изергиль». На основі власних спостережень I. Кондрашева пропонує такі висновки: «Новий методологічний конгломерат вимагав зображення того, щүо $є$ в житті (реалізм), але й того, щ⿻ може утворитися в результаті позитивної еволюиї изього сущуого (реальне життя в ї̈ революиійному розвитку) ... треба було злити в єдине філософське $і$ методологічне цุіле те, щзо за своєю природою фактично не об'єднується» [Кондрашева 2003 : 42]. Філософсько-методологічне «злиття» становило суть праці про новий реалізм М. Горького. Не менш цікавою $є$ й проблема концепції особистості. Так, І. Кондрашева міркувала: «Як вивести формулу авторського відношення до людини, авторської концеепџї особистості, якщуо в письменницькому арсеналі ідей часто опиняються найсуперечливі задуми ... у кожному окремому випадку (у структурі характерів) $\epsilon$ якась надія на перемогу мрії, якщо навіть в глибині душі особа таємно від інших i від себе часто тримає думки про неможливість ї̈ реалізації. Перебування героя ураз у двох світах (світ реальності $і$ світ мрії...) дає письменникові можливість проектувати ідеї в їх перспективі, хоча їх еволюиія нерідко призводить до руйнування обох світів» [Кондрашева 2003 : 43]. Прикладом таких спостережень дослідниці послуговував роман «Фома Гордеев». У складному синтезі різних форм і засобів (жанровостильових, ідейно-поетичних) спостерігаються явні письменницькі інтенції на зображення соціальних процесів, які випали на його долю i час існування у світі. Тому головне спостереження I. Кондрашевої становить суть неореалізму: «Як ніколи раніше, письменники часів “нового реалізму” сміливо $і$ рімуче осмислюють суспільні $i$ сочуіальні подї, включаючи в художній текст живу, пристрасну публіцистику <..> прагнучи небагатьма словами, словами-знаками висловити основне, найвірніше $i$ необхідніме» [Кондрашева 2003 : 51-52].

У дослідженнях П. Басинського і С. Федякіна представлена інша панорама джерел нового реалізму М. Горького. Зародження нового 
відображення дійсності автори вбачали у пошуках «красної словесності», притаманних XIX ст. Наполягаючи на взаємозв’язку літературного руху XX століття 3 попередньою епохою, науковці виказували пропозиції одного із стійких концептуальних положень філософів-неореалістів про неодмінний лінійний взаємозв'язок будь-яких явищ із попередніми традиціями i впливовість цих явищ на наступний етап розвитку. 3 попереднього XIX століття у XX перейшли дві категоріальні форми словесності: «реальна» та «ідеальна». Їхнє взаємозлиття і протиборство, відмінність i спільність являли суть основних літературних проблем $\mathrm{XX}$ століття, зокрема у становленні, а з часом і визначенні завдань нового реалізму. За певними доказами дослідників, реалізм «володів пальмою першості в галузі прози», хоча і засвідчив своє місце у поезії І. Буніна. Однак у прозі ані символісти, ані футуристи, чи акмеїсти не могли зрівнятися 3 новими реалістами І. Буніним, О. Купріним, М. Горьким, Л. Андреєвим, I. Шмельовим, . Зайцевим [Басинский $1998: 23$ ]. Безперечними авторитетами для М. Горького були Л. Толстой і А. Чехов. Їм письменник присвятив нариси «А. П. Чехов» (1904) і «Лев Толстой» (1919). Чеховська естетична художність для письменника мала надзвичайно важливе значення. Первісні риси нового реалістичного пошуку автори вбачали у А. Чехова і називали його першим «новим реалістом, щзо здійснив у прозі “делікатну”, але вельми серйозну революиіюю» [Басинский 1998 : 29]. Для М. Горького стали прийнятними основні риси чеховського реалізму, до нових якостей якого вчені відносили знаменитий авторський лаконізм «перетворити невелику сатиричну розповідь на художній шедевр» (на прикладі твору «Дочь Альбиона»). Головне, на щзо звернули увагу дослідники, - изе те, щзо «Чехов позначив початок нового, символічного реалізму. Але зробив це не за рахунок відмови від реалізму, а за рахунок граничної концентрації його можливостей, коли він як би “переростав” сам себе і перетворювався на абсолютний реалізм, реалізм “у квадраті”» [Басинский 1998 : 29]. Надзвичайно суттєвим компонентом нового реалістичного напряму 
М. Горького літературознавці називали філософське підгрунтя творів. Особливий настрій горьківської філософії автори пояснювали соціальним походженням письменника: «... як ніхто 3 російських письменників Горький рано зіткнувся з недосконалістю людської природи у самій низовинній суті. Жорстокість, грубість, неосвіченість й інша “краса" провінційного побуту отруїли його душу, але й - парадоксальним чином породили велику віру в Людину $i$ його потенціийні можливості. Це протиріччя створило особливий настрій <..>, де Людина (ідеальна сутність) не просто не збігалася з людиною (реальною істотою), а й вступала з ним у трагічний конфлікт» [Басинский 1998 : 61]. До нових якостей горьківського реалізму науковці відносили гуманізм М. Горького «це гуманізм без берегів - поза часом і простором» та оптимізм - «ц̧ей оптимізм теж поєднував у собі крайнощзі: відчуття якнайглибшої кризи, в якій виявилася Людина напередодні і на початку XX cm, $і$ віру в те, щзо ияю кризу можна здолати силами самої Людини» [Басинский 1998 : 61]. Риси нових реалістичних відображень П. Басинський та С. Федякін широко дослідили в оповіданні «Бывшие люди», романах «Фома Гордеев» і «Мать», п’єсі «На дне».

У неореалістичних позиціях С. Тузкова висловлюються неоднозначні думки про існування розгалужених спрямувань у природі неореалізму. Автор виділяв рух нового реалізму наприкінці XIX століття, у специфіці якого вбачав ліричний присмак. Неореалізм він представив у вигляді формули «реалізм + романтизм», а внутрішніми розгалуженнями такої форми називав суб'єктивно-сповідувальну парадигму (творчість В. Гаршина і В. Короленка) та суб'єктивно-об'єктивну парадигму (творчість А. Чехова). На початку XX століття неореалізм для дослідника дорівнюється формулі «реалізм + модернізм», у якому він виділив імпресіоністично-натуралістичну парадигму (твори Б. Зайцева, О. Купріна, М. Арцибашева), екзистенційну парадигму (творчість М. Горького, Л. Андреєва, В. Брюсова), міфологічну парадигму (творчість Ф. Сологуба, О. Ремізова, М. Пришвіна), сказово-орнаментальну парадигму (твори 
Андрєя Бєлого, Є. Замятіна, I. Шмельова). Нескладно помітити, що неореалістична творчість М. Горького для літературознавця має філософську спрямованість. На прикладі повісті «Городок Окуров» дослідник пропонує власні висновки про художню своєрідність митця, вважаючи, що після повісті виникло уявлення про «нового Горького». Суть новаторства закладена в авторській позиції, яку С. Тузков «прочитав» у підтексті повісті: «“вестернізація” Росії, відмова від споглядальності Сходу на користь дійсності Заходу» [Тузков 2009 : 149]. На шляху до нового герої обирають різні дороги: проповідь, бунт, молитву, покаяння. Однак згубність і безперспективність цих шляхів очевидна, оскільки вони «упираються у стіну нерозуміння, яка зростає у свідомості обивателя на грунті страху свободи».

Розвинену характеристику неореалізму М. Горького подали сучасні автори праць про новий реалізм XX століття В. Захарова і Т. Комишкова, I. Кондрашева, П. Басинський i T. Комишкова поставили ряд ключових питань про неореалізм: про нове художнє мислення, духовні засади творів, феноменологію художньої свідомості, оновлення реалістичного письма, специфіку епічних жанрів, подолання споглядальності в оповіданнях, національний характер. Джерелами неореалізму (як нового типу художнього мислення) М. Горького автори називають чеховську сферу художності, а в ранній прозі письменника підкреслюють типологічну спорідненість із майстерністю I. Буніна, Б. Зайцева, I. Шмельова, С. Сергеєва-Ценського «внаслідок спрямування до естетичного синтезу, що поєднував у собі піднесену символічність, генетично висхідну до чеховської, яскраву романтичну основу, риси імпресіоністичної поетики, експресіонізму, неоміфологизму» [Захарова $2008: 25]$. До нових якостей художності літературознавці відносили низку різних авторських жанрово-стильових пошуків: чітке вираження сюжетної основи, форми авторської присутності у тексті, особливу активність просторової образності, створення ефекту глибокої внутрішньої співвіднесеності навколишнього світу 3 життям героїв, органічний сплав реальної життєвої конкретики, акцентуацію на 
символічній деталі, емоційно маркований філософський план, створення «складного комплексу квінтесенцій». Зазначені риси, на думку вчених, спостерігаються майже в кожному творі письменника, зокрема, в оповіданнях «Каин и Артем», «Скуки ради», «Мальва», «Бывшие люди», «Коновалов», «Супруги Орловы», «26 и одна», «Окуровском цикле», в циклі «По Руси», у повісті «Жизнь Матвея Кожемякина», романах «Трое» i «Фома Гордеев». Кожному із згаданих творів приділено увагу в теоретичній праці про неореалізм у російській прозі $\mathrm{XX}$ століття В. Захарової та Т. Комишкової. На основі аналізу творів автори дійшли певних висновків: у текстах спостерігається «видимий негатив щодо укладу людського буття у порівнянні 3 прекрасним природним світом»; навколишній світ виступає як активний рівнодійний 3 персонажами узагальнений, живий і динамічний образ; надзвичайний антропоморфізм природи і неживого світу, всього, що оточує людину; образ світу тісно пов'язаний $з$ емоційно-психологічним станом героя, допомагає створити «незвичайний суб'єктивований образ світу»; створення психологізму нового типу «коли на перший план висувається емоційний пласт душевних рухів героїв, а для його розкриття використовується місткий синтез колоритної метафоричної образності» [Захарова 2008 : 26]. У повісті ряд визначальних неореалістичних рис поширюється за рахунок «ефекту стиснення часу» та створення «позафабульної сфери образної виразності». Приклади художньої майстерності формували особливу образну сферу тексту, в якому поряд із лаконічністю існував потужний філософський потенціал висвітлення онтології існування.

\section{БІБЛІОГРАФІЯ}

Басинский 1998 - Басинский П. В. Русская литература конца XIX - начала $\mathrm{XX}$ века и первой эмиграции : [пособ. для учителя] / П. В. Басинский, С. Р. Федякин. - М. : Академия, 1998. - 528 с.

Браун 1993 - Браун Э. Дж. Символическое влияние на «реалистический» стиль Горького / Э. Дж. Браун // Русская литература XX века. Исследования американских ученых. - СПб. : Изд-во Петро-РИФ, 1993. - С. 156-175. 
Бялик 1974 - Бялик Б. А. Рождение социалистического реализма в творчестве М. Горького / Б. А. Бялик // Развитие реализма в русской литературе : в 3 т. - М. : Наука, 1974. - Т. 3. - С. 247-303.

Венгеров 1909 - Венгеров С. А. Основные черты истории новейшей русской литературы / С. А. Венгеров. - СПб. : Издательство «Общественная Польза», 1909. - 88 с.

Гречнев 1979 - Гречнев В. Я. Русский рассказ конца XIX-XX века (проблематика и поэтика жанра) / В. Я. Гречнев. - Л. : «Наука», Ленинградское отделение, 1979. - 208 с.

Захариева 2003 - Захариева И. Символизм и своеобразие русского реализма ХХ века / И. Захариева // Болгарская русистика. - 2003. - № 3-4. С. 31-39. -Режим доступу до журналу : http://www.russian.slavica.org/userimages/ raharieva_realism_09.pdf

Захарова 2008 - Захарова В. Т. Неореализм в русской прозе XX века : типология художественного сознания в аспекте исторической поэтики : [учебное пособие] / В. Т. Захарова, Т. П. Комышкова. - Н. Новгород : НГПУ, 2008. $113 \mathrm{c}$.

Катаев 2000 - Катаев Б. Б. Реализм и натурализм / Б. Б. Катаев // Русская литература рубежа веков (1890-е - начало 1920-х годов). - Книга 1. ИМЛИ РАН. - М. : Наследие, 2000. - С. 191 - 258.

Келдыш 1975 - Келдыш В. А. Русский реализм начала XX века / В. А. Келдыш. - М. : Наука, 1975. - 280 с.

Кондрашева 2003 - Кондрашева И. И. Поиски Художественного синтеза. Размышления об особенностях художественного синтеза в символизме и «неореализме» русской литературы рубежа векав / И. И. Кондрашева. - Майкоп : Изд-во МГТИ, 2003. - 55 с.

Луначарский 1958 - Луначарский А. В. Статьи о советской литературе / А. В. Луначарский. - М. : Учпедгиз, 1958. - 478 с.

Тузков 2009 - Тузков С. А. Неореализм : Жанрово-стилевые поиски в русской литературе конца XIX - начала XX века [учебн. пособие] / С. А. Тузков. - М. : Флинта : Наука, 2009. - 336 с. 